\title{
ANALISIS FAKTOR YANG MEMPENGARUHI INTENSI POLA HIDUP BERSIH DAN SEHAT PADA MASYARAKAT DI BANTARAN SUNGAI CITARUM
}

\section{Analysis of Faktors Affecting the Clean and Healthy Lifestyle Intention in the Community on the Citarum Watershed}

\section{Ikhsan Fuady $^{1}$, Ditha Prasanti ${ }^{2}$ Sri Seti Indriani ${ }^{3}$}

1,2,3 Fakultas Ilmu Komunikasi Universitas Padjadjaran Jl.RayaBandung Sumedang Km 21 jatinangor 54363 Indonesia

\begin{abstract}
Abstrak
Perma salahan pola hidup sehat yang buruk memiliki pera n yang besar terhadap permasalahan kesehatan pada masyarakat di hulu bantaran Sungai Citarum. Penelitian ini bertujuan untuk menganalisis fa ktor faktor yang mempen garu hi in ten si ma syarakat dalam berperilaku pola hidup sehat. Metode penelitian ini kuantitatif dengan pendekatan survey. Berda sarkan ha sil penelitian diketahui bahwa intensi perila ku masyarakat dalam perilaku hidup bersih dan sehat terkategori sed ang. Ada pun faktor faktor yang mempengaruhiintensi perila ku pola hidup sehat adalah faktor sika p mas yarakat terhadap kesehatan itu sendiri dan noma subjektif Sikap yang positif pada pola hidup sehat sebagai faktor do minan y ang mempengaruhi intensi untuk berperila ku hidup sehat. Norma subjektif yang memilikiperan signifikan te rhadap intensi adalah dukungan lingkungan sekitar dan tokoh masyarakat.
\end{abstract}

Kata kunci: Intensi, perilaku PHBS, sikap.

\begin{abstract}
Problems with poor healthylifestyles have a large role in health problems in the upstream communities of the Citarum River. This studyaims to analyze the faktors that influence the intention of the community in healthy lifestyle be havior. This research method uses quantitative methods with a survey approach. Basedon the results of the study it was found that the intention of community behavior in clean and healthy living behavior was categorized as being. The faktors that influence the behavior intention of a healthy lifestyle arefaktors in people's attitudes towards health itselfand subjective norms or external support for healthy behaviors. A positive attitude towards healthy lifestyles is the dominant faktor that influences the intention to have a healthy lifestyle. Subjectivenorms that have a significant role in in tention are the support of the surrounding environment and community leaders. Keywords: intention, PHBS behavior, attitude.
\end{abstract}

Keywords: Intention, behaviora, l PHBS, attitute 


\section{PENDAHULUAN}

Pencemaran limbah domestik dan aktivitas pertanian masyarakat di DAS Citarum telah menyebabkan penurunan kualitas air sungai (Fulazzaky, 2010) mengungkapkan bahwa penuurunan kualitas air pada DAS Citarum semakin meningkat akibat pembuangan limbah di wilayah Hulu Citarum tanpa adanya pengolahan. Berdasarkan hasil analisis diketahui kualitas air pada umumnya berkualitas buruk dan tidak baik untuk pemanfaatan konsumsi air minum, dan kegiatan kegiatan oleahraga di darah hulu bendungan Saguling.

Aktifitas masyarakat yang tinggal di bantaran Sungai Citarum ini memiliki permasalahan kesehatan yang memprihatinkan bagi masyarakat, akibat pemanfaatan air sungai yang tidak tepat dan sikap terhadap pola perilaku sehat yang buruk. Wangsaatmaja dalam (Cahyaningsih \& Harsoyo, 2010) mengungkapkan di bantaran Sungai Citarum Jawa Barat telah dibuktikan ada hubungan yang nyataa antara lokasi disepanjang sungai Citarum Hulu (hulu-hilir) dengan kejadian penyakit bawaan air. Resiko menderita penyakit bawaan tertinggi di Ciserung dengan nilai OR sebesar 276 untuk penyakit kulit dan 14,636 untuk penyakit diare (potensi banjir tertinggi setiap tahunnya), Katapang dan Nanjung nilai OR untuk penyakit kulit 0,866 dan 0,479 dan penyakit diare sebesar 1,178 dan 2,029, Andir dan Cijeruk OR untuk penyakit kulit sebesar 26,833 dan 1,568 dan untuk penyakit diare sebesar 5,664 dan 1,178 .

Berdasarkan data dari Bidang Pengendalian Penyakit dan Penyehatan Lingkungan (P2PL) Dinas Kesehatan Kabupaten Bandung, jumlah penderita ISPA atau pneumonia balita pada Juli 2017 mencapai 644 kasus. Sedangkan jumlah penderita diare hing ga Juli 2017 mencapai 1.282 kasus.

Semakin meningkatnya permasalahan permasalahan kesehatan masyarkat yang tinggal di bantaran sungai Citarum, tidak lepas dari sikap dan dan literasi perilaku pola hidup sehat masyarakat setempat.
Berdasarkan permasalahan di atas, bagaimana sikap dan literasi perilaku pola perilaku sehat masyarakat, serta faktor faktor yang mempengaruhinya merupakan suatu hal yang menarik dikaji. Penelitian ini selaras dengan percepatan pencapaian SDGs dan Commons goal Jawa Barat yaitu Meningkatkan aksesibiltas dan kualitas layanan kesehatan (1). Peningkatan pelayanan kesehatan dasat di puskesmas, puskesmas PONED, dan pemenuhan sumber daya kesehatan (2). Pemenuhan palayanan kesehatan dasar ibu dan anak serta tujuan (4). Pemberantasan penyakit menular dan penyakit tidak menular serta peningkatan prilaku hidup bersih dan sehat.

Mengetahui dan mengidentifikasi faktor yang menyebabkan niat berperilaku bersih dan sehat masyarakat dibantaran sungai merupakan sangat penting sebagai upaya untuk mengidentifikasi permasalahan dan strategi penyelesaian permasalahan msayarakat dibantaran sungai. Oleh karena itu penelitian ini mengambil judul "Analisis faktor faktor yang mempengaruhi intensi PHBS masyarakat di Bantaran Sungai Citarum kabupaten Bandung". Adapun tujuan dari penelitian ini adalah untuk mengetahui faktor faktor yang mempengaruhi intensi PHBS masyarakat di bantaran Hulu Sungai Citarum kabupaten Bandung.

Dalam menjelaskan perubahan perilaku, model yang sering digunakan dalam menganalisis dari perspektif psikologi adalah menerapkan Theory of Planned Behavior (TPB) . Kerangka teori yang digunakan pada penelitian ini adalah dengan menggunakan konsep dalam komunikasi lingkungan serta Theory of Planned Behavior (TPB). Banyak studi saat ini yang menerapkan Theory of Planned Behavior (TPB) untuk memprediksi niat perilaku tertentu. Sebuah tinjauan literatur menemukan beberapa penelitian sebelumnya tentang niat perilaku (Chan, 1998; Gao, 2017) telah menerapkan Theory of Planned Behavior (TPB) mendukung model mereka. Apalagi banyak penelitian internasional baru-baru ini dilakukan tentang isu isu kesehatan dan lingkungan telah menggunakan TPB sebagai landasan kerangka 
teoretis (Albayrak, Aksoy, \& Caber, 2013). Banyak peneliti selain yang diidentifikasi faktor yang mempengaruhi intensi dengan menerapkan TPB diperluas sebagai dasar teoritis untuk mempelajari apakah konsumen berniat melakukan perilaku tertentu (Chan \& Bishop, 2013; Chen \& Tung, 2014; Greaves, Zibarras, \& Stride, 2013) . (Nikou \& Economides, 2017.) menambahkan variabel persepsi Pengaruh Sosial, Kecemasan, kesibukan, kesesuaian diri, keyakinan dalam mengindetifikasi faktor yang mempengaruhi intensi. Sementara itu (Cristea \& Gheorghiu, 2016) menambahkan variabel persepsi terhadap resiko. Penelitian penelitian tentang pengujian teori tindakan berencana dalam konten intensi dan perilaku masyarakat telah banyak dilakukan. (Swaim, Maloni, Napshin, \& Henley, 2014) sikap merupakan variabel terkuat dalam mempengaruhi intensi serta memvalidasi variabel sosial norm dan PBC. Hal serupa juga diungkapkan (Augusto, Borges, Willian, \& Oude, 2016), (Papadimitriou, 2018), (Kl, 2017), (Gao, 2017), (Chen \& Tung, 2014) menggunakan teori TPB untuk menjelaskan intensi perilaku masyarakat. Berdasarkan studi literatur ini, dalam konteks intensi dalam perilaku BHBS, peneliti mencoba menganalisis faktor faktor apa yang mempengaruhinya intensi masyarakat dalam perilaku PHBS di hulu DAS Citaraum.

\section{METODE PENELITIAN}

\section{Kerangka Pemikiran}

Pada metode penelitian memuat secara rinci metode yang digunakan dalam penelitian mulai dari tempat penelitian, sampel, variabel, metode yang digunakan dan analisis yang dilakukan. Metode penelitian harus menjelaskan sumber rujukan yang jelas yang memungkinkan untuk diulang orang lain dan jika metode dimodifikasi harus dijelaskan dengan singkat.

Penelitian didesain sebagai penelitian kuantitatif dengan metode survey. Berdasarkan tujuan umum penelitian, peneliti berusaha mengetahui faktor faktor yang mempengaruhi intensi individu pola perilaku sehat. Untuk mencapai tujuan tersebut peneliti mendesain penelitian yang bersifat menerangkan (explanatory research). Menurut (Babbie, 1992) penelitian bersifat menerangkan adalah penelitian survey yang bertujuan menjelaskan pengaruh dan hubungan antar peubah melalui pengujian hipotesis.

Faktor faktor yang mempengaruhi Intensi atau niat individu dalam pola hidup bersih dan sehat, dipengaruhi oleh beragam faktor, mulai dari karakteristik individu, karakteristik lingkungan sosial budaya. Secara umum dalam memprediksi perilaku dapat dilakukan pada dua pendekatan atau teori, yaitu dari teori perilaku berencana dan teori orientasi nilai. Pada penelitian ini, peneliti akan menguji faktor faktor yang mempengaruhi intensi masyrakat dalam perilaku hidup bersih dan sehat dari kerangka teori tindakan berencana. Berdasarkan teori, kerangka penelitian ini digambarkan pada gambar.1

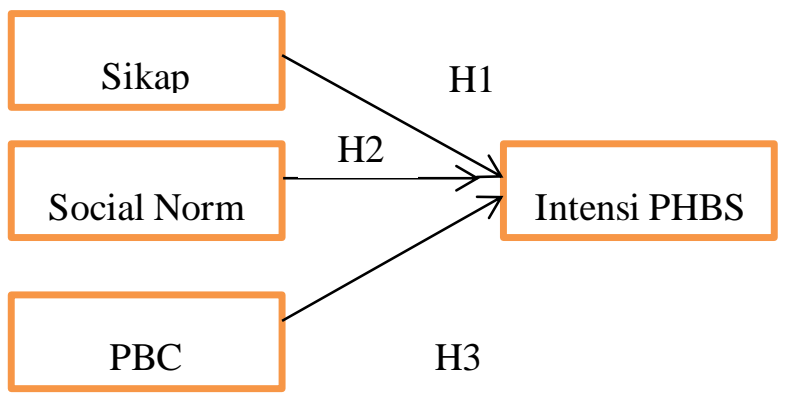

Gambar 1. Faktor faktor yang mempengaruhi intensi pola hidup bersih dan sehat.

Berdasarkan gambar di atas, penelitian ini akan menguji bagaimana pengaruh sikap pola hidup sehat, sosial norm, dan persepsi tentang perilaku hidup bersih dan sehat terhadap intensi atau niat untuk berperilaku hidup bersih dan sehat.

\section{Pengumpulan Data}

Penelitian ini didesan sebagai penelitian survey. Metode survey digunakan untuk pengumpulan data dari seluruh anggota populasi. Ciri khas pengumpulan data melalui survey adalah data dikumpulkan dari sejumlah responden dengan menggunakan kuesioner. Keuntungan utama dari 
survey adalah dimungkinkannya membuat generalisasi untuk populasi berdasarkan analisa terhadap sampel yang berasal dari populasi tersebut.

Penelitian dilaksanakan di daerah hulu Sungai Citarum yang merupakan yang termasuk kedalam wilayah Administratif Kabuaten Bandung Propinsi Jawa Barat.

Lokasi Penelitian terletak di Desa Tarumajaya, Kecamatan Kertasari. Penentuan lokasi dilakukan secara sengaja dengan pertimbangan kawasan ini merupakan daerah aliran hulu sungai yang sebagian di permukiman warga yang menggunakan air Sungai Citarum yang tercemar untuk kebutuhan sehari hari. Waktu pelaksanaan penelitian dilakukan survey pada Bulan Februari 2018 -Juli 2018. Populasi penelitian ini adalah warga ibu rumah tangga di Desa kertasari. Sampel penelitian ini adalah sebagaian dari populasi yang diambil secara simple random sampling sebanyak 39 responden.

\section{Analisis Data}

Penelitian ini menggunakan kerangka teori tindakan berencana dari ajzen, intensi perilaku individu diduga dipengaruhi oleh sikap individu, social norm dan perceive behavior control. Intensi merupakan keinginan untuk berperilaku, sedangkan Sikap menurut ajzen adalah keyakinan dan evaluasi individu terhadap suatu objek, pengukuran dimensi sikap ini diukur dengan parameter keyakinan dan evaluasi individu tentang perilaku PHBS. Social norm merupakan pandangan lingkungan sekitar terhadap suatu objek bersifat mendukung ataupun tidak. Pengukuran variabel ini dengan parameter dukungan keluarga dan masyarakat untuk berperilaku bersih dan sehat. Untuk variabel perceive behavior control merupakan persepsi individu terhadap perilaku. Pengukuran variabel ini dengan parameter persepsi inidvidu tentang kemampuan dalam berbagai dimensi untuk melakukan perilaku PHBS. Untuk menjawab tujuan penelitian ini, analisis data yang digunakan adalah dengan menggunakan statistika deskriptif dan statistik inferensia. Statistik deskriptif digunakan untuk menggambarkan sikap masyarakat terhadap perilaku hidup sehat, sedangkan statistik inferensi, uji yang digunakan adalah dengan regresi linier berganda. Fungsi regresi pada penelitian ini dijabarkan pada persamaan berikut:

$Y=a \pm b 1 X 1 \pm b 2 X 2 \pm b 3 X 3+e$

Dimana:

$\mathrm{Y}:$ Intensi perilaku

A : Konstanta

B : koefisien korelasi

$\mathrm{X}_{1: \text { Sikap }}$

$\mathrm{X}_{2}$ : social norm

$\mathrm{X}_{1: \text { perceive behavior control }}$

\section{HASIL DAN PEMBAHASAN}

Pola hidup sehat merupakan sikap penting yang harus dimiliki setiap individu. Permasalahan kesehatan pada masyarakat yang tinggal dibantaran sungai merupakan permasalahan yang yang penting untuk diselesaikan karena kondisi lingkungan DAS Citarum yang mengalami degradasi dan pencem aran yang semakin mengkhawatirkan. Permasalahan semakin meningkatnya permasalahan warga di bantaran sungai tidak lepas dari pola hidup masyarakat yang tinggal di bantaran sungai tersebut. Mengetahui faktor faktor yang mempengaruhi perilaku bersih dan sehat masyarakat dibantaran sungai merupakan sangat penting sebagai upaya untuk mengidentifikasi permasalahan dan strategi penyelesaian permasalahan msayarakat dibantaran sungai.

Pada dasarnya, karakteristik masyarakat yang tinggal di bantaran sungai Citarum memiliki literasi kesehatan yang beragam tentang pentingnya perilaku hidup sehat tersebut. Ada warga desa yang memiliki masyarakat aktif dan telah melek informasi kesehatan tersebut, tetapi ada juga warga desa yang memprihatinkan dari aspek literasi kesehatan tersebut. Pada penelitian ini akan menganalisis faktor 
faktor yang mempengaruhi intensi masyarakat dalam perilaku Hidup sehat.

\section{Faktor Faktor yang Mempengaruhi Intensi Masyarakat Bantaran Sungai Citarum}

Intensi atau niat individu dalam melakukan pola hidup sehat pada masyarakat di kawasan hulu sungai Citarum relatif beragam. Sebagian besar mereka sudah memiliki intensi yang cukup baik meskipun belum semua perilaku masyarakat mencrminkan pola hidup sehat yang baik, karena banyak faktor yang mempengaruhinya.

Hipotesis penelitian ini, diduga faktor sikap, norma subjektif (social norm), dan persepsi terhadap perilaku PHBS memiliki pengaruh terhadap intensi atau niat individu dalam melakukan perilaku pola hidup sehat pada masyarakat di bantaran sungai Citarum. Sikap adalah kondisi mental dan neural yang diperoleh dari pengalaman, yang mengarahkan dan secara dinamis mempengaruhi respon-respon individu terhadap semua objek dan situasi yang terkait. Krech \& Crutchfield (1948). Norma subyektif berhubungan dengan pandangan seseorang terhadap suatu keadaan atau kejadian, dan perasaan yang timbul apabila seseorang tidak mengikuti pandangan orang lain atas suatu keadaan atau kejadian. Norma subjektif adalah persepsi seseorang mengenai tekanan sosial untuk melakukan atau tidak melakukan perilaku (Ajzen, 1991). Kontrol perilaku yang dirasakan mengacu pada persepsi orang tentang kemudahan atau kesulitan melakukan perilaku yang diminati. Peranan kontrol perilaku memainkan peran penting dalam teori perilaku terencana dan merupakan variabel penyempurnaan dari teori tindakan beralasan.

Berdasarkan hasil analisis dengan mengunakan uji regresi linier berganda dengan SPSS 20 for windows dengan metode backward. Metode backward dalam regresi adalah satu metode dimana pengujian dengan multi tahap untuk mendapatkan model terbaik. Berdasarkan uji tahap satu diketahui variabel social norm dan perceive behavioral control tidak memilki pengaruh signifikan pada alfa lima persen. Pada tahap dua variabel perceive behavioral control otomatis didrop. Berdasarkan hasil pengujian kedua didapatkan model terbaik dari uji regresi ini yang digambarkan pada Table. 1

Tabel 1. Uji regresi linear pengaruh sikap, variabel social norm dan perceive behavioral control terhadap intensi perilaku:

\begin{tabular}{lllll}
\hline \multicolumn{5}{c}{ Standardized } \\
Model & $\begin{array}{l}\text { Coefficients } \\
\text { Beta }\end{array}$ & T & Sig. \\
\hline $1 \quad$ (Constant) & & 1,40 & 0,17 \\
& Att & 0,37 & 2,28 & 0,03 \\
& Sc & 0,30 & 1,85 & 0,07 \\
& Pbc & 0,03 & 0,20 & 0,84 \\
$2 \quad$ & (Constant) & & 2,00 & 0,05 \\
& Att & 0,38 & 2,48 & 0,02 \\
& Sc & 0,31 & 2,04 & 0,05 \\
\hline
\end{tabular}

Sumber: Analisis da ta primer.

Berdasarkan hasil analisis data pada Tabel.1. ini diketahui faktor faktor yang mempengaruhi intensi masyakat dalam pola hidup sehat adalah variabel sikap masyarakat dan variabel social norm. hal ini dapat diketahui dari uji parsial uji t, menunjukan bahwa nilai signifikasi kedua variabel lebih kecil dari 0,05 , atau dengan nilai $t$ hit $>$ dari $t$ tabel pada alfa 5 persen. Sedangkan untuk variabel perceive behavioral control tidak memiliki pengaruh yang nyata pada selang kepercayaan 95 persen. Berdasarkan hasil analisis di atas, maka dapat di bangun persamaan faktor faktor yang mempengaruhi intensi masyarakat sebagai berikut;

$Y=28,753+0,375 X 1+0,309 X 2+e$

Dimana:

$\mathrm{Y}:$ Intensi masyarakat

$\mathrm{X}_{1}$ : Sikap PHBS

$\mathrm{X}_{2}$ : Social Norm

PHBS merupakan semua perilaku kesehatan yang dilakukan atas kesadaran sehingga anggota keluarga atau keluarga dapat menolong dirinya sendiri di 
bidang kesehatan dan berperan aktif dalam kegiatankegiatan kesehatan di masyarakat. Intensi atau niat masyarakat dalam perilaku hidup bersih dan sehat merupakan suatu keinginan ataupun niat seseorang dalam melakukan perlaku hidup sehat yang meliputi; persalinan ditolong oleh tenaga kesehatan, memberi bayi ASI eksklusif, menimbang bayi dan balita, menggunakan air bersih, mencuci tangan dengan air bersih dan sabun, menggunakan jamban sehat, memberantas jentik di rumah, makan buah dan sayur setiap hari, dan melakukan aktivitas fisik setiap hari serta tidak merokok di dalam rumah. Perilaku BHBS pada masyarakat bantaran Sungai Citarum, secara umum sangat dipengaruhi oleh aspek sikap masyarakat terhadap PHBS itu sendiri dan juga social norm atau persepsi orang lain terhadap individu yang melakukan PHBS itu.

\section{Pengaruh Sikap Terhadap Intensi Perilaku Hidup Bersih dan Sehat}

Dalam teori tindakan berencana, menyatakan bahawa sikap individu terhadap suatu objek memiliki pengaruh yang positif terhadap intensi individu dalam berperilaku. Sikap yang dapat mendorong seseorang berperilaku antara lain adalah sikap yang kuat, semakin kuat sikap maka cenderung untuk berperilaku sebagaimana sikapnya. Berdasarkan hasil analisis pada tabel 1, diketahui intensi masyarakat dalam perilaku hidup sehat dipengaruhi cukup kuat oleh sikap masyarakat itu sendiri, dengan koefisien pengaruh sebesar 0,375 , dengan nilai signifikasi 0.018 lebih kecil dari tingkat kesalahan alfa 5 persen atau dengan kata lain nilai $t_{\text {hitung }}>t_{\text {tabel. }}$. Berdasarkan hasil analisis data, model pengaruh sikap terhadap intensi dapat digambarkan pada bersamaan berikut;

$Y=28,753+0,375 X 1+e$

Dimana:

Y: intensi pola hidup bersih dan sehat masyarakat

$\mathrm{X}_{1}$ : sikap masyarakat

Berdasarkan persamaan di atas, peningkatan satu satuan sikap dapat meningkatkan intensi masyarakat sebesar 0,375 satuan. Sikap individu terhadap PHBS sangat erat kaitannya dengan intensi individu. Sikap individu yang positif tentang PHBS akan cenderung menguatkan individu untuk melakukan perilaku PHBS. Sikap masyarakat terhadap perilaku PHBS yang meliputi sepuluh dimensi secara umum dapat dikategorikan cukup tinggi dan kategori sedang. Indikator PHBS yang cukup rendah antara lain pada aspek makan buah dan sayur setiap hari, dan melakukan aktivitas fisik setiap hari serta tidak merokok. Distribusi sikap masyarakat dalam pola hidup sehat dapat dijelaskan pada table 2 .

Tabel 2. Sebaran frekuensi sikap masyarakat terhadap PHBS

\begin{tabular}{lll}
\hline $\begin{array}{l}\text { Sikap masyarakat } \\
\text { terhadap PHBS }\end{array}$ & Frekuensi & Persentase (\%) \\
\hline Tinggi & 14 & 36 \\
Sedang & 21 & 54 \\
Rendah & 4 & 10 \\
Jumlah & 38 & 100 \\
\hline
\end{tabular}

Sumber: a nalisis data primer

Berdasarkan tabel 2 di atas, diketahui sebagaian besar masyarakat dapat dikategorikan ke dalam masyarakat yang memiliki sikap tentang pola hidup sehat terkategori sedang, yaitu sebanyak 54 persen, sedangkan masyarakat dengan sikap positif yang tinngi dan rendah berturut turut adalah 36 persen dan 10 persen. Sebagai besar masyarakat memiliki sikap yang baik pada dimensi persalinan ditolong oleh tenaga kesehatan, memberi bayi ASI eksklusif, menimbang bayi dan balita, menggunakan air bersih, mencuci tangan dengan air bersih dan sabun, menggunakan jamban sehat, memberantas jentik di rumah, sedangkan pada aspek makan buah dan sayur setiap hari, dan melakukan aktivitas fisik setiap hari serta tidak merokok terkategori sedang dan rendah.

\section{Pengaruh norma subjektif terhadap intensi perilaku hidup bersih dan Sehat}

Norma subyektif berhubungan dengan pandangan seseorang terhadap suatu keadaan atau kejadian, dan perasaan yang timbul apabila seseorang tidak mengikuti pandangan orang lain atas suatu keadaan atau kejadian. Norma subjektif adalah persepsi 
seseorang mengenai tekanan sosial untuk melakukan atau tidak melakukan perilaku (Ajzen, 1991). Dalam model theory of reasoned action dan theory of planned behavior, norma subjektif adalah fungsi dari normative beliefs, yang mewakili persepsi mengenai preferensi significant others yaitu apakah perilaku tersebut harus dilakukan. Norma subyektif banyak dikaji pada penelitian-penelitian psikologi, seperti penelitian tentang intensi berwirausaha (Andika \& Iskandar, 2012) menunjukkan norma subyektif memiliki pengaruh terhadap intensi berwirausaha mahasiswa. Norma sosial diperoleh dari mendenganrkan saran orang-orang terdekat.

Sebuah norma subyektif adalah fungsi dari keyakinan normatif dan motivasi untuk mematuhi perilaku yang diharapkan. Sebuah keyakinan normatif mengacu pada sejauh mana individu memandang perilaku tertentu atau kondisi yang diharapkan dan diinginkan dalam pikiran orang lain yang penting bagi individu. Motivasi untuk mematuhi perilaku yang diharapkan mengacu pada bagaimana memaksa individu untuk memenuhi berbagai harapan. Seseorang akan merasakan bahwa teman-temannya, keluarga, dan rekan kerja berpikir tentang suatu keyakinan yang dapat mempengaruhi niat seseorang melakukan suatu tindakan.

Berdasarkan hasil analisis pada tabel 1, diketahui intensi masyarakat dalam perilaku hidup sehat dipengaruhi cukup kuat oleh norma subjektif masyarakat itu sendiri, dengan koefisien pengaruh sebesar 0,309, dengan nilai signifikasi 0.049 lebih kecil dari tingkat kesalahan alfa 5 persen atau dengan kata lain nilai $t_{\text {hitung }}>t_{\text {tabel. }}$. Berdasarkan hasil analisis data, model pengaruh sikap terhadap intensi dapat digambarkan pada bersamaan berikut;

$Y=28,753+0,309 X 2+e$

Dimana:

Y: intensi pola hidup bersih dan sehat masyarakat

$\mathrm{X}_{1}$ : norma subjektif masyarakat

Berdasarkan persamaan di atas, peningkatan satu satuan norma subjektif dapat meningkatkan intensi masyarakat sebesar 0,309 satuan. Norma subjektif individu terhadap PHBS sangat erat kaitannya dengan intensi individu. Norma subjektif individu yang positif tentang PHBS akan cenderung menguatkan individu untuk melakukan perilaku PHBS. Berdasarkan hasil wawancara pada sebagain responden diketahui bahwa perilaku individu untuk melakukan pola hidup sehat dipengaruhi oleh dukungan orang orang terdekat seperti anggota keluarga dan tokoh masyarakat. Apresiasi ataupun dukungan pihak ekternal sangat mempengaruhi individu untuk berperilaku bersih dan sehat.

\section{KESIMPULAN DAN SARAN}

\section{Kesimpulan}

Pola hidup sehat merupakan sikap penting yang harus dimiliki setiap individu. Permasalahan kesehatan pada masyarakat yang tinggal dibantaran sungai merupakan permasalahan yang yang penting untuk diselesaikan karena kondisi lingkungan DAS Citarum yang mengalami degradasi dan pencemaran yang semakin mengkhawatirkan. Permasalahan semakin meningkatnya permasalahan warga di bantaran sungai tidak lepas dari pola hidup masyarakat yang tinggal di bantaran sungai tersebut. Mengetahui faktor faktor yang mempengaruhi perilaku bersih dan sehat masyarakat dibantaran sungai merupakan sangat penting sebagai upaya untuk mengidentifikasi permasalahan dan strategi penyelesaian permasalahan msayarakat dibantaran sungai.

Berdasarkan hasil penelitian ini dapat disimpulkan bahwa, sikap pola hidup bersih dan sehat di hulu bantaran sungai Citarum ini, terkategori sedang. Adapun faktor yang mempengaruhi masyarakat untuk berperilaku bersih dan sehat adalah faktor sikap masyarkat itu sendiri dan juga faktor norma subjektif yang dipandang oleh masyarakat. Sementara itu variable persepsi terhadap perilaku tidak memiliki pengaruh yang signifikan terhadap intensi perilaku PHBS. Peningkatan intensi masyarakat untuk berperilaku hidup bersih dan sehat 
dalapt dilakukan dengan menanamkan nilai dan sikap pola hdiup bersih dan sehat serta menguatkan nilai nilai dukungan sosial di masyarakat.

\section{Saran}

Berdasarkan hasil temuan ini, saran dalam upaya peningkatan intensi untuk perilaku hidup bersih dan sehat adalah, setiap upaya edukasi atau penyadaran masayrakat, hendaknya memperhatikan aspek sikap masyarakat dan juga social norm atau norma subjektif masayrakat. Sehingga perubahan intensi inidvidu dapat ditingkatkan.

\section{Daftar Pustaka}

Ajzen, I. (1991). The theory of planned behavior. Orga $n$. Behav. Hum. Decis. Process. (Vol. 50 (2)).

Albayrak et al. (2013). T.Albayrak, S. Aksoy, M. CaberThe effect of environmental concern and scepticism on green purchase behaviour Mark. In tell. Plan. 10.1108/02634501311292902.

Andika, M. dan Iskandar, M. (2012). Analisis Pengaruh Sikap, Norma Sub Yektif Dan Efikasi Diri Terha dap Intensi Berwirausaha Pada Mahasiswa Fakultas Ekonomi Universitas Syiah Kuala (Studi Pada Mahasiswa Fakutas Ekonomi Universitas Syiah Kuala). Universitas Negeri Semarang, Fakultas Ekonomi.

Augusto, J., Borges, R., Willian, L., \& Oude, A. G. J. M. (2016). Land Use Policy Using the theory of plan ned beha vior to identify key beliefs underlying B ra zilia cattle farmers ' intention to use improved natural grassland:AMIMIC modelling approach. Land Use Policy.

Babbie, E. (1992). The practice of social rese arch (Edisi Enam.Belmonted.). Ca lifornia: Wadsworth Publishing Company.

Cahyaningsih, A., \& Harsoyo, dan B. . (2010). DISTRIBUSI SPASIAL TINGKATPENCEMARAN AIR. Sains \& Teknologi Modifikasi Cuaca.

Chan and Bishop,. (2013). L. Chan, B. BishopA moral basis for recycling: extending the the ory of pla nned beha viour. J. Environ. Psychol, 36, 96-102.

Chan, K. (1998). Mass communication and proenvironmental behavior: waste recycling in Hong Kong. Journal of Environmental Management, 52 (4), 317-325.

Chen, M.F., Tung, P.J. (2014). Developing an extended theory of planned behavior model to predict consumers intention to visit green hotels. Int. J.Hosp., 36, 221 230 .
Cristea, M., \& Gheorghiu, A. (2016). Attitude, perceived behavioral control, and intention to adopt risky beha viors. Transportation Research Part F: Psychology and Behaviour, 43, 157-165.

Fulazzaky, M. (2010). Water quality evaluation system to assess the status and the suitability of the Citarum river water to different uses. Environmental Monitoring and Assessment.

Ga o, 1. Et.al. (2017). Application of the extended theory of planned behavior to understand individual 's en ergy saving behavior in workplaces. Resources, Conservation \& Recycling 127 (2017) .

Grea ves, M., Zibarras, L.D., Stride, C. (2013). Using the theory of planned behavior to explore env iro nmental behavioral intentions in the workplace. J. Environ. Psychol. 34, 109-120.

$\mathrm{Kl}$, C. A. . (2017). A stage model as an analysis framework for studying voluntary change in food choices e The case of beef consumption reduction in Norway, 108. https://doi.org/10.1016/j.appet.2016.11.002.

Nikou \& Economides. (2017.). Mobile-based assessment: Investigating the faktors that influence behavioral intention to use. J. Computers \& Education, 109, 56 73.

Papadimitriou, D. (2018). The Role of Theory of Plan ned Behavior on Entrepreneurial Intention of Greek Business Students (Vol. 4(1)).

Swaim, J. A., Maloni, M. J., Napshin, S. A., \& Henley, A. B. . (2014). Influences on Student Intention and Behavior Toward Environmental Sustainability. https://doi.org/10.1007/s10551-013-1883-z. 